Article

\title{
Sustainability and Competitiveness of Romanian Farms through Organic Agriculture
}

\author{
Mirela Ionela Aceleanu \\ Department of Economics and Economic Policy, Faculty of Theoretical and Applied Economics, \\ The Bucharest University of Economic Studies, Romana Square, No.6, 010374 Bucharest, Romania; \\ aceleanu_mirela@yahoo.com or mirela.aceleanu@economie.ase.ro; Tel.: +40-72-307-9799 \\ Academic Editor: Filippo Sgroi \\ Received: 14 October 2015; Accepted: 1 March 2016; Published: 7 March 2016
}

\begin{abstract}
Currently, the development of any sector involves respecting the principles of sustainability, which means economic, social and environmental development. Moreover, organic farming is a very important field for ensuring sustainable development. Romania has great potential for the development of organic agriculture, especially due to the large number of available farmland and reduced use of fertilizers and other chemicals. However, the development of organic farming in Romania is in an early stage, due to the numerous problems that Romanian agriculture is still facing. Concern for the environment should be reflected at the level of production processes and consumption. As market demand influences and stimulates production, we can ask the question to what extent stimulating the consumption of organic products through green marketing can boost organic agriculture development and competitiveness of Romanian farms. Using several methods of research, such as analysis, synthesis, comparison, statistical methods and by calling on studies, reports and data series on organic farming in the EU and Romania, this paper highlights Romania's position in terms of the level of development of organic agriculture and recommends several ways to improve the outcomes obtained by Romania in the field. Moreover, based on regression equations, the trend of convergence of Romanian organic agriculture development in relation to the EU countries is analysed. The paper demonstrates that one of the measures that can be taken by Romanian farms is green marketing strategy development that can stimulate both consumption and production of organic products. Therefore, with increasing interest in the development of organic agriculture in Romania, green marketing can play an increasingly important role in promoting the benefits of consuming organic products, thus contributing to business development of organic products as well as to the development of Romanian agriculture. Promoting organic agriculture through the use of green marketing techniques is useful for improving human, environmental and economic health, in the context of sustainable development.
\end{abstract}

Keywords: sustainable development; organic agriculture; green marketing; Romanian farms

\section{Introduction}

Currently, environmental issues are gaining growing importance in ensuring greater economic development. Globalization and urbanization affect lifestyle and consumer behavior. Sustainable economic development involves the promotion of environmentally friendly policies, at any economic level, and the transformation of consumption and production so that human and economic activities support a sustainable society. Also, environmental problems cannot be ignored in the drafting of policies for growth and development within the new paradigm of sustainable development.

Evaluation of an economic system requires a special focus on the principles of efficiency, fairness and respect for nature. Raising the interest in environmental issues, the behavior of the different actors involved in the economic process changes in response to new trends and requirements. Profit 
maximization has to be inseparably associated with consideration for environmental issues, as consumers will realize the imperative to protect the environmental for current and future generations. Equity concerns, however, the need to mitigate the effects these changes currently have and avoiding putting additional pressure on the most vulnerable and the poorest.

In this context, in which care for the environment has to be considered in all fields and their production, distribution and consumption processes, we can ask the following questions: Is organic farming a way of assuring the sustainability and competitiveness of Romanian farms? What measures should we take so that we could stimulate the production and consumption of organic products in Romania? Is green marketing strategy a solution for this purpose?

Sustainable development imposes new methods of production and consumption, as well as new methods of business organization in which the environment, nature and quality of life become the main pillars of any strategy.

The evolution of organic production depends on the demand for organic products and the consumption behavior of consumers.

Sustainable consumption behaviour occurs when consumers have two positive attitudes: firstly, as regards sustainability and environment and, secondly, when there is a greater personal responsibility and involvement displayed [1]. While companies have a responsibility to provide food options for consumers that are healthier and more environmentally friendly, consumers have the responsibility to make efficient selections, minimizing food waste, given that a third of all food produced worldwide is lost annually [2,3].

In terms of green marketing, it is important those in business understand it from a holistic perspective, where maintaining a healthy environment is one of their main objectives.

Green marketing, as a strategic and holistic approach to current management, has to identify, meet and anticipate the needs of various participants without affecting the welfare of individuals or of nature. The main task of green marketing is awareness of environmental health, present and future, so that consumers accept payment for this purpose, the direct costs as well as higher prices for green products, or opportunity costs reflected by the changes in their lifestyles.

The work presents the situation of Romanian agriculture and its potential to develop organic production, assuring the sustainability and competitiveness of farms. Starting from the fact that the largest part of current production of organic products is designed for export, and the domestic demand is low, this work proposes analyzing to what extent a green marketing strategy could stimulate the consumption of organic products.

We identified the strengths of this area, and the problems facing Romanian agriculture in relation to the European Union, too. Romanian organic farming has a high development potential, especially because of the large areas of agricultural land owned by Romania that, up to now, have not been exposed to excess chemical fertilizers and pesticides.

The paper aims to identify the extent to which green marketing can be a useful strategy to support the development of Romanian organic agriculture in order to keep up with highly developed countries. The development of organic farming in Romania involves not only the development of environmentally friendly agricultural production practices but also the development of sales, distribution and ecological consumption processes. All these processes can contribute to the creation of a competitive green market, both domestically and internationally.

The present research uses multiple research methods such as: synthesis, analysis, comparison and statistical analysis, taking into account the research data series on the evolution of organic agricultural land in the EU and Romania, in order to become detached from the regression equation trend convergence or divergence of the economies in the EU.

\section{Organic Products: Sustainability and Competitiveness of Organic Farming}

In specialized literature, studies about the quality and limits of organic products compared to non-organic products are multiple. 
The term organic refers to the way in which the producer/farm grows agricultural products. It aims at conservation of soil and water, requires the use of natural manure and no use of fertilizers or chemical products in the production process. Nutrition specialists argue that the organic products are richer in nutrients, vitamins and antioxidants, which is beneficial for health, because they help increase immunity and reduce the risk of food allergies [4,5].

Some studies show that the percentage of these substances is $19 \%-69 \%$ higher in organic products than in conventional products. Some say the benefits of organic products are exaggerated, because these differences can appear as a result of the types of soil or cultures used and climate, not necessarily stemming from the type of agriculture practiced. Furthermore, the benefits for health are also thought to be exaggerated taking into account that some studies show that the scientific proofs are not enough to demonstrate the major differences between organic products and non-organic products [6].

A complex study performed by a team of researchers from Newcastle University highlights the qualities of organic products from the point of view of higher content of antioxidants and lower content of heavy toxic metals and pesticides. Unlike other studies, it uses data from 343 peer-review publications and adopts modern statistical methods, being the most extensive study on this subject in recent years [4].

Due to its lower impact on the environment and the effects organic products have on health, organic farming is undergoing continuous expansion.

Organic agriculture is a very important field for ensuring sustainability and the transition to the green economy, this field having a major impact on the natural environment. Organic farming involves food security, whilst ensuring human and environmental health, because in the production stage, the organic farm does not use genetically modified organisms, fertilizers, pesticides, hormones and antibiotics, and, in the processing stage of organic food, the use of additives and chemical substances is restricted. Organic farming, unlike conventional practices, requires ensuring soil fertility without the use of chemical fertilizers and pesticides, the banning of genetic modifications to plants, crop rotation and recycling of waste. Therefore, the EU supports organic farming by increasing the production of organic products and the number of consumers [7].

Organic agriculture has grown in importance as an issue of common EU policy since 1991, when EU issued two regulations that defined organic farming and introduced support for organic agriculture as a means of environmentally friendly production. The member countries implemented these regulations in the subsequent years, legal and financial instruments influencing the development of organic farming, but financial support was of greatest importance in the development of these farms [8]. Michelsen and Soegaard (2001) considers that at the basis for the development of organic farming in the EU stood factors such as state financial support and the moral attitude of farmers who saw in organic farming a way of improving quality of life and developing contacts with supermarkets and other institutional networks [9].

The Common Agricultural Policy (CAP) has been and continues to be instrumental in supporting organic farming at the EU level. The impact of the CAP reform on the economic situation was positive, especially for organic arable farms, due to the financial support that farmers received. The CAP reform involved "a reduction in price support coupled with compensatory payments and the introduction of agri-environmental programmes", which had a positive impact on the competitiveness of organic farms [10].

Within the rural development programmes covering the period to 2020, organic farmers are financially supported over a period between five and seven years, with relevant legislation being reviewed and improved [11].

Economically speaking, in the scientific literature there is concern for how profitable organic farming is because it can develop and extend as far as it is competitive against conventional farming.

The main long-term objective of any company is profit maximization. However, the sustainability and competitiveness of a company requires, on the one hand, ensuring a balance between profit 
maximization and environmental protection, and, on the other hand, obtaining and maintaining a favourable market position, attracting a greater number of customers and loyalty.

Crowder and Reganold's study [12] shows that the development of organic agriculture is important for ensuring global food security, for biodiversity and the environment. They demonstrate that although organic farming has lower yields than conventional farming, it is more profitable and has great potential for expansion. The results of this research are based on over 120 studies, which show that even if organic farming produces approximately $10 \%-18 \%$ less than the conventional farming, additional prices (up to $30 \%$ higher) that customers pay for green products cover the costs of organic farmers and ensures their profitability.

The process of becoming an organic farmer, however, is not very easy. There are costs in acquiring organic crops, preparing land, and labour, in addition to obtaining a lower production compared to conventional production. Some studies stress the importance of analysing the variability in environmental impacts during the conversion period. Hokazono and Hayashi [13] compared three rice production systems in Japan—organic, environmentally friendly, and conventional—and reached the conclusion that "only the environmental impacts associated with organic farming fluctuated widely over the years across all impact categories, and these fluctuations diminished over time". The higher environmental impact for organic production and higher variability in the impacts of organic farming at the initial phase is explained by the instability of organic production performance.

Sgroi et al. [14] demonstrates that transition from conventional to organic production, in the case of olives, is justified by increasing profitability, increasing biodiversity, reducing soil erosion and reduced environmental impact. The cost-benefit analysis underpinning the conclusions of this study shows that organic farms have higher profitability as a result of CAP subsidy and of the price of organic products, which can be $21 \%$ higher than in case of conventional products. The same results are also obtained by Testa et al. [15] with regard to the profitability of the production of green lemons. Financial indicators under analysis show a clear advantage of organic production compared to the conventional production, in the case of lemons in an area of Sicily. This was due to fewer labour requirements and the higher price that consumers pay for organic products.

Starting from some points of view in the literature that argue that organic farming is not always less harmful to the environment than conventional farming, Mohamad et al. [16] demonstrate based on the case of production of organic olives from Apulia, a region of Italy, that organic production has less impact on the environment, particularly due to the reduced use of fossil fuels and the use of manure for fertilizing the soil. However, the authors stress the importance of using modern agricultural technologies, such as electrically-driven irrigation systems, mechanical weeding and biological pest control, to reduce costs on the environment and also to develop environmentally friendly products.

The profitability and competitiveness of organic farms can be supported by government policies, through subsidies, tax reduction, ensuring disposal of organic products, facilitating the transition of conventional farmers to organic farming and supporting entrepreneurship in the field.

Supporting organic farming by government policies requires both economic instruments and legislation. For example, economic instruments can be: market price support, target prices, market regulations, direct support, fees and excise taxes. The direct support aims at supporting the production, subsidies and direct investment in developing this sector, and indirect support is based on research, education and extension services [17].

The objectives of food security and food poverty reduction are not incompatible with sustainable agriculture, if they are included in rural development strategies and policies. Sustainable agriculture promotes rural development while preserving natural resources and protecting the environment. Conventional agriculture by cultivating commercial crops leads to changes in ecosystems and environmental pressures. Sustainable agricultural practices have to, therefore, include activities based on the rehabilitation of degraded agricultural land and on the cultivation of organic products [18]. 


\section{Romanian Agriculture Status and the Development of Organic Farming in the Context of Sustainable Economy}

It is unanimously recognized the need and role of agriculture in any economy, be it development in the classic sense, but especially if we talk about sustainable development.

The European Union is concerned with organic production, the first action plan being developed in 2004 for future organic production. The last action plan [7] shows that the overall challenge facing the organic sector is to ensure steady growth of supply and demand, and, at the same time, consumer confidence. It is essential to ensure credibility of the system and added value from a long-term perspective. The new Multiannual Financial Framework 2014-2020 aims to continue to support Structural Funds and Cohesion program in all regions of the EU Cohesion Fund (Investment Environment), European Regional Development Fund, ERDF (investments for developing technologies and infrastructure) and the European Social Fund, ESF (investment in human capital).

In Romania, the level of agriculture development and the industry-s characteristics can give us information about the extent to which the promotion of organic farming may stimulate green consumption and, thus, can contribute to the sustainability and competitiveness of organic farms.

The Romanian agricultural sector is still underdeveloped, facing problems with land fragmentation, low technological development, high share of employment with low productivity, inefficient output, and population aging. It is worth highlighting in this context, that of the total labor force in agriculture, only a small percentage is employed, the rest being self-employed and unpaid family workers. Thus, it is difficult in Romania to ensure the current mass production practices in agriculture align with the standards of a green economy, requiring additional costs or risks, especially due to the low use of modern technologies and techniques.

The gross added value of agriculture in GDP has decreased recently. In the year 2014, it was 5.4\% of GDP. Even if the percentage of population employment in agriculture is decreasing, the gross added value of agriculture is quite high $(25 \%$ in the year 2014) if we take into account the contribution of this sector to GDP. The two indicators (employment in agriculture and gross added value) show that Romanian agriculture has still a low efficiency (Figure 1). This is explained by the use of outdated technologies, land fragmentation, and insufficiently developed infrastructure.

For Romanian agriculture, the problem of the increased vulnerability of workers (compared to those in other industries) to labour market changes can be solved by moving these workers to other sectors [19]. Organic agriculture represents in these cases a successful solution, aiming to solve both labour market and environmental problems.

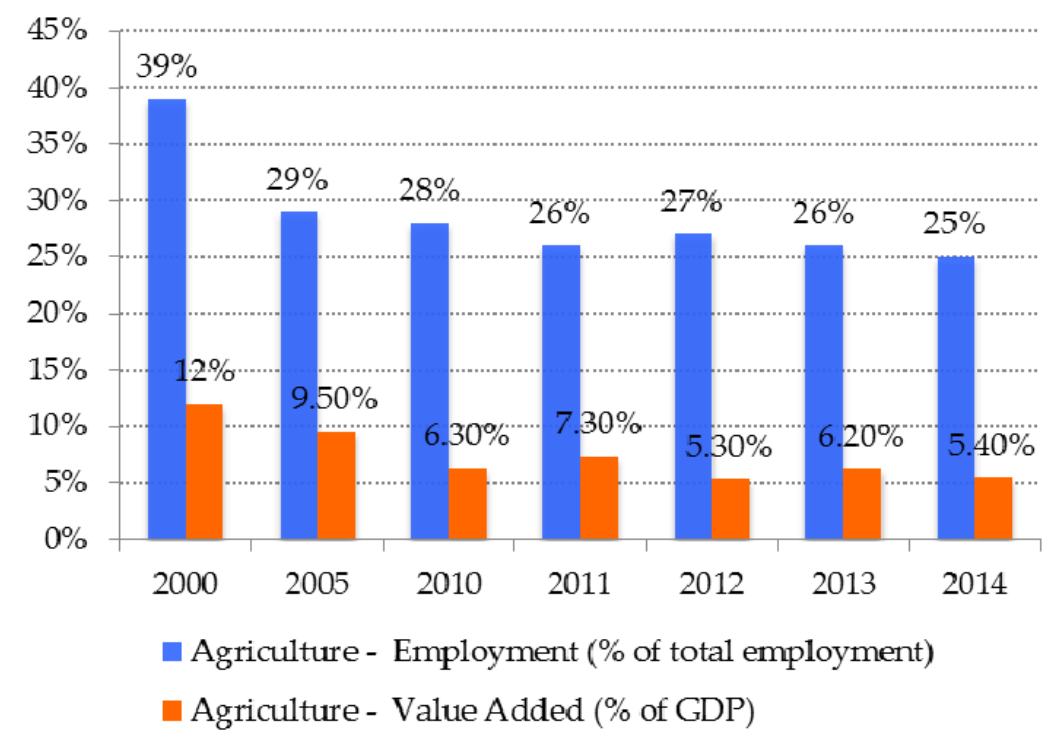

Figure 1. Employment and value added in Romanian agriculture. Source: World Bank [20,21]. 
At the same time, both in the EU and in Romania, the farming population is aging. At EU level, $30 \%$ of farmers are in the age group 65 and over and only $8 \%$ of them are under the age of 35 years [6]. We wonder if the aging population employed in agriculture in Romania can show the openness necessary for implementing organic farming. Family farms in Romania represent over 99\% of all farms, with only $7 \%$ under 35 and $38 \%$ of managers aged over 65 years. Also, these trends are reflected more broadly in the EU. Some differences appear in terms of the age of non-family managers of farms, where $13 \%$ of managers in Romania are younger than 35, compared with $9 \%$ in the EU.

The problems facing Romanian agriculture, mentioned above, limit the development of the agricultural sector in terms of the requirements of a sustainable/green economy. However, the transformation of a traditional farm into an organic farm involves additional risks and costs. These include the loss of productivity that the farmer may experience during the transition from traditional agriculture to organic agricultures whereby organic products may take longer to be produced (no longer subject to rapid growing and harvesting techniques) and the extra costs associated with labor or the purchase of large modern technologies, as well as much lower crop yields from not being able to use certain techniques to stimulate plant growth/cultures.

Growing demand for green products as a result of understanding and awareness of the importance of the organic sector and, therefore, the promotion of organic products through green marketing has led the favorable development of this sector at the EU level.

In the period 2005-2012, on average 508,088 hectares were converted to organic production annually, showing an average increase of $6.5 \%$ per year (growth rate of organic land).

In 2012, at EU level, the total area used for organic production (including both certified surfaces and those undergoing conversion) was over 10 million ha, according to the official statistics of the EU, comprising $5.7 \%$ of the total utilized agricultural area [22]. In Romania, this indicator stood at $2.1 \%$ in 2012, indicating a low level of organic farming, but, nonetheless, an increase in organic production in Romania (Figure 2). In 2005 this indicator was only $0.7 \%$ and in 2010 was $1.3 \%$. The first national legislation on organic farming was implemented in Romania in 2000, which highlights the low level of experience of Romania in this field [23].

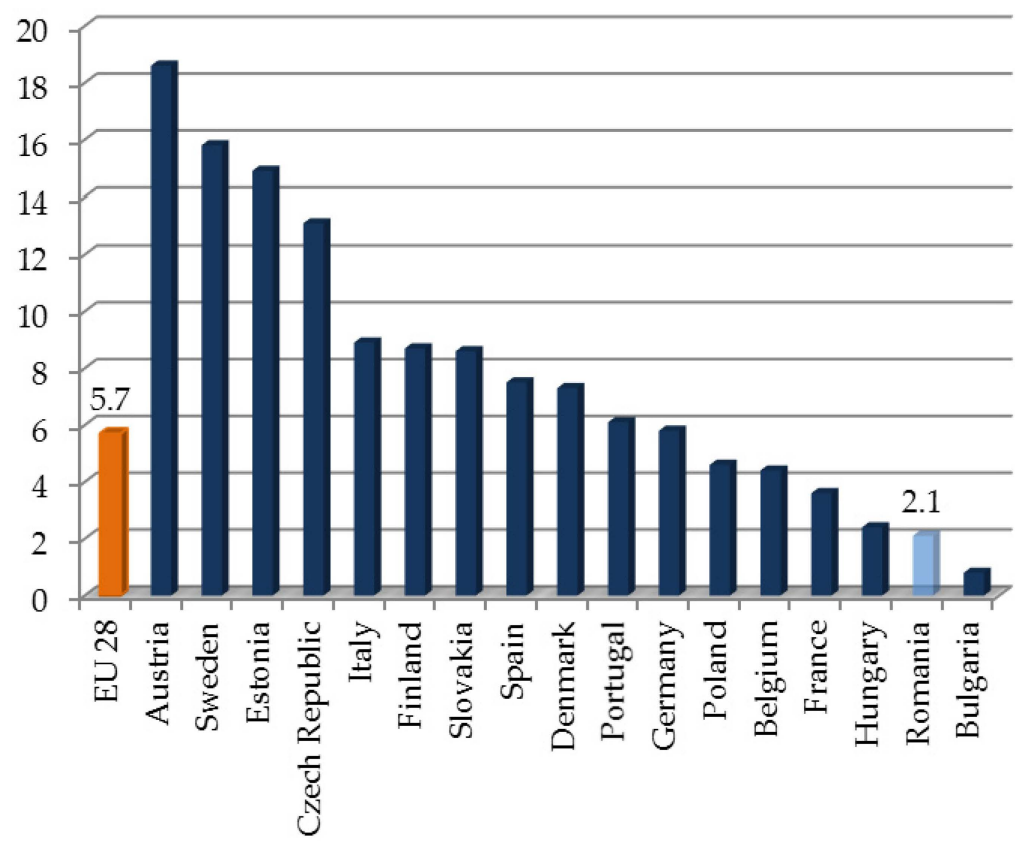

Figure 2. Share of organic agriculture of total agriculture (\%), 2012. Source: Eurostat, 2015 [23].

The development of organic farming in Romania is observed by increasing the number of certified operators in organic farming and the utilized agricultural area. Figure 3 captures the evolution of the 
number of operators and agricultural area used for organic farming in Romania and shows the growth of these indicators in the period 2006-2013. This growth has boosted exports of organic products from Romania. Over $90 \%$ of Romanian bio production is exported to countries like UK, Italy, Germany, and Spain, and the products with the highest export share are honey, fruit and oil [24]. Also, the largest quantities of organic products of animal origin in 2014 were raw milk, drinking milk, butter and cheese.

A problem regarding the efficiency of the organic agricultural sector is related to the fact that exports are mainly raw materials and less are processed products, which would add more gross value.

A slight downward trend is observed in Figure 3 of the number of operators in organic farming in 2008-2010, which may be explained by the financial problems caused by the economic and financial crisis, which has hindered the development of this field. In the period 2010-2012, a significant increase in organic certified operators was recorded, which is explained by the development of agribusiness, supported by European funds. European funding has stimulated both the agricultural entrepreneurship development and the emergence of new farms [25].

However, in Romania, the consumption in Euro, per capita for the purchase of green products is only 3.4 Euro per capita, which can be compared to Switzerland, Denmark and Austria, where the consumption exceeds 100 euro [10].

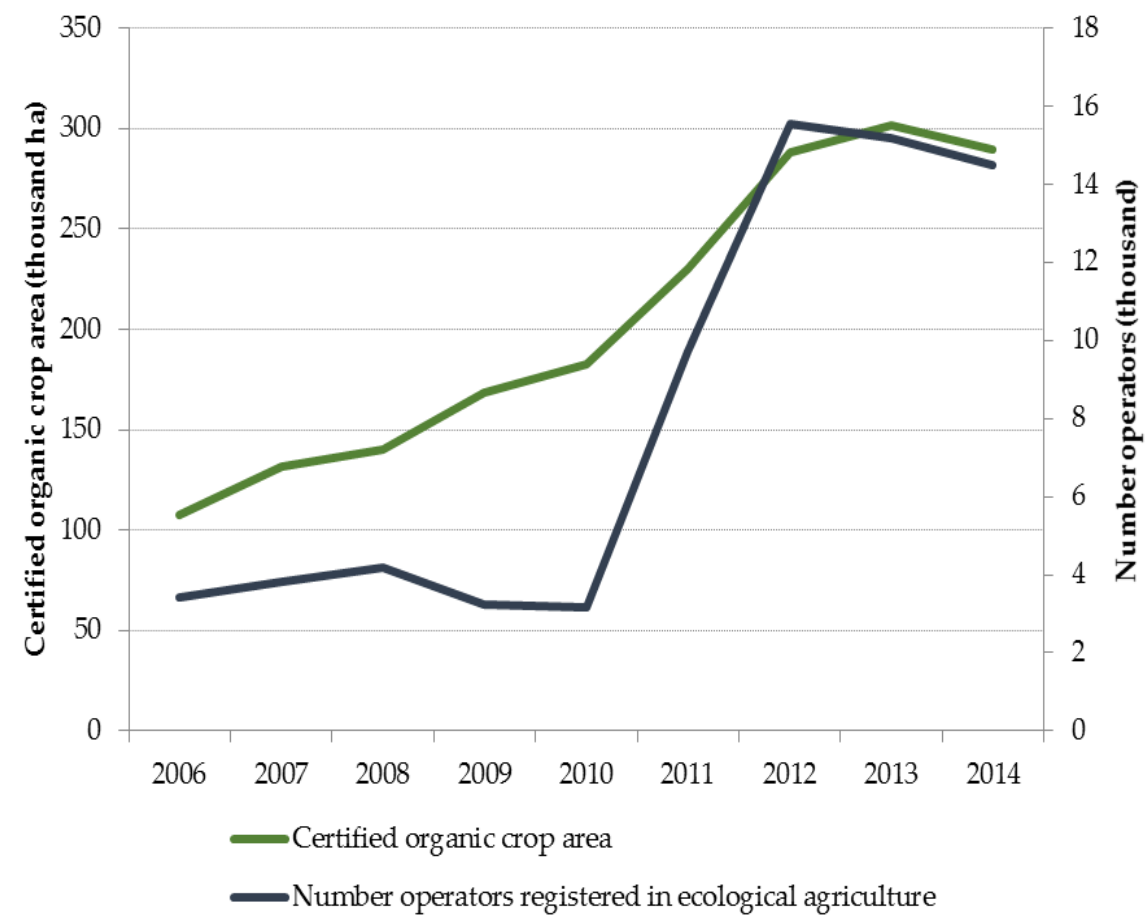

Figure 3. Evolution of number of operators and total agricultural area used for organic agriculture (ha), in Romania, 2006-2014. Source: Eurostat and MARD 2014 [22,25].

From the total surface area designed for organic farming, the largest area is represented by cereals, dry pulses (seeds) and industrial agriculture (Figure 4).

Amid growing interest for organic agriculture and promotion of a green economy, the EU has adopted numerous projects to finance the development and modernization of farms and rural areas. Current requirements are aimed at creating competitive farms that apply environmental sustainable techniques. The products should satisfy marketing regulations, which require farmers to provide better information to consumers about the composition of products and their origin. In these marketing standards, green marketing plays an increasingly important role in organic farming, which ensures that environmental standards have been met, so that the environmental impact is minimized. Romania must adapt to these trends so as to follow the path of ensuring sustainable economic development. 


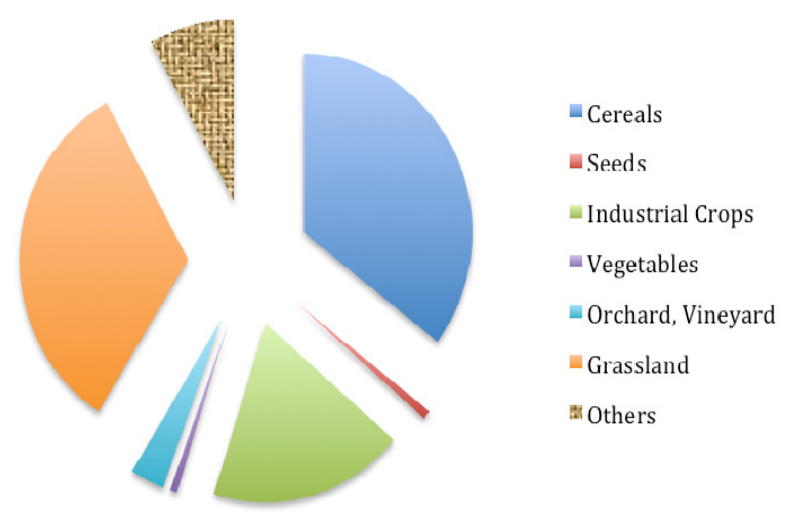

Figure 4. Share of organic culture surfaces of total organic agricultural surface area (\%) Romania, 2014.

Source: MADR, 2014 [22,25].

The hypothesis of the existence of an inverse relationship between the growth rate of agricultural land used for organic production (2005-2012) and the initial size of these areas (2005), as shown in neoclassical theory on decreasing returns to capital, support convergence in the EU in terms of this indicator. According to the equation, it follows that there is a process of convergence between Romania, a country with a low amount of land used for organic production, and countries performing well on this indicator. As shown in Figure 5, countries that have the lowest levels of organic production areas as a percentage of total area in 2005 recorded the highest growth rates for this indicator in 2005-2012. The countries Poland, Bulgaria, Cyprus, Romania and Malta, which in 2005 recorded organic agricultural areas less than $1 \%$ of the total agriculture area, increased their shares of organic farmland to total utilized agricultural area by $300 \%-500 \%$. Romania increased this share from $0.7 \%$ to $2.1 \%(300 \%)$ in the period under review, working to reduce disparities between countries in the EU in terms of this indicator and highlighting a positive trend.

Thus, in 2005, in Romania, the share of organic farming areas stood at less than $20 \%$ compared to the EU average in 2012 of around $37 \%$.

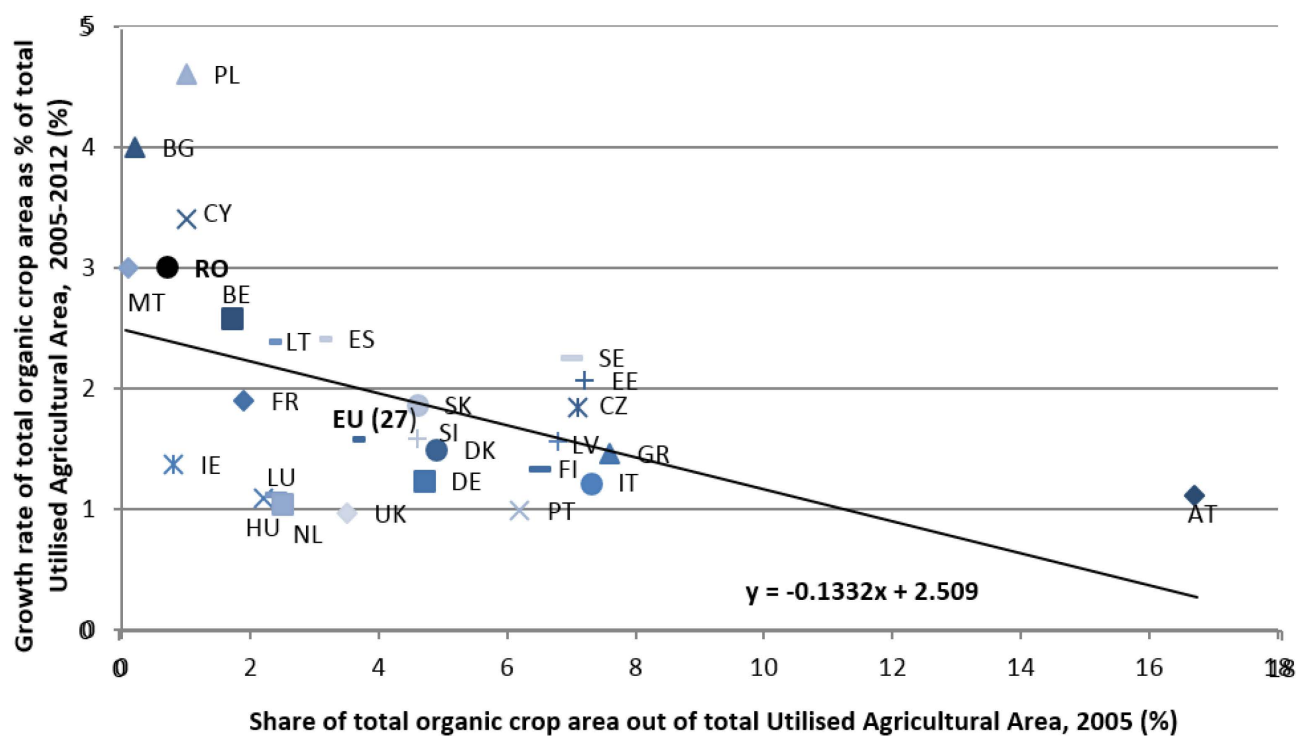

Figure 5. Romania-EU convergence process in terms of surface area share for organic farming of total agriculture area, 2005-2012. Source: Eurostat 2015 [26].

The development of organic farming in Romania is based on developing existing farms and creating new farms, to align with the quality requirements imposed by EU rules. 
Development and promotion of organic farming in Romania depends on rural development, which requires increased investment in agriculture and non-agricultural activities, and development of infrastructure, services and rural tourism. An important aspect for rural development is training farmers in line with the European vision of the modern farmer who demonstrates professionalism, and aspires to develop healthy and environment friendly agriculture.

Also, infrastructure and the distribution system of products for Romanian farms should be developed. Farmers need to be able to access markets at the local, regional and global level and, for this, it is important to improve access to transport, storage and market facilities [27].

In this sense, Lohr et al. [28] highlights the importance of direct sales of organic products that benefit both consumers and producers. Direct sales of organic agricultural products through local distribution channels such as farmers' markets may allow producers to achieve higher profit margins and increase revenue. This type of sale is gaining ground, especially for small farmers and organic producers. So, food products' marketing is an opportunity for producers to further develop their products. Studies suggest that organic farmers are flexible and open to applying marketing strategies to enhance their ability to sell products and attract more customers. Establishing local markets through direct sales to consumers brings advantages both in terms of reducing some costs as well as creating a direct link with the customer, which can help to provide important feedback to the producer [28].

Sustainable development policy must be correlated with other macroeconomic policies: agricultural policy, industrial policy, employment policy, educational and tax policy, etc. For sustainable agriculture, the development of renewable energy, the creation of green jobs, the adoption of green industrial technologies, and the granting of tax breaks are all important aspects. They collectively respond to the demands of creating a green economy, which entails the promotion and implementation of green production processes at the firm level and changing consumer behavior at the individual level [29].

\section{Is Green Marketing a Way to Support Development of Organic Agriculture in Romania?}

\subsection{Green Marketing in Theory and Practice}

In order to develop a sustainable economy, concerns for developing green production and green consumption have increased. In the scientific literature, the role of green consumption to stimulate green production and move to a green economy is widely debated and requires increased accountability at individual and firm levels as well as at the governmental level.

Green consumption requires both the consumption of organic products as well as limiting wasteful consumption, recycling and reuse of goods and reduced energy consumption [30].

Nowadays, there is an increased interest in green issues, reflected in organic food consumption, the use of alternative sources for energy, among other behaviors, especially among people with high education (directly correlated with income level). Education helps people to be more informed and understand the positive aspects of green economic development for human health and the environment. The European Union recognizes both the importance of green marketing and providing information about organic products and the need for education, knowledge and specific technologies to support sustainable development [22].

The link between the level of education, income, demographic variables and ecological behaviour of consumers is shown in Fuller's study [31] who suggests that particularly the educated, young and higher-income people comprise green consumers.

However, Riley et al. show that age does not matter in environmental consumer behaviour; there are segments of older consumers who demonstrate ecologically conscious behaviour, and at the same time, there are segments that do not [32].

Polonsky et al., using the Theory of Reasoned Action, on a sample of US consumers, show that there is a positive relationship between general knowledge about environmental protection (education) and consumer attitude towards the environment (consumer behaviour). Therefore, the authors highlight the 
role of marketing in developing consumer knowledge in order to influence environmentally friendly consumer behaviour [33]. Indeed, there is an attitude behaviour gap because of this, a positive environmental attitude does not automatically translate into environmental behaviours.

Recent years have seen a growing interest among consumers in the purchase and consumption of organic food. Increasingly, more consumers' purchase decisions are based not only on price but also on the content and quality of the product.

Thogersen et al. show the reasons why the consumer buys organic food-nutrition, taste, and environmental friendliness. "Social norms play a minor role for the intention to buy organic food, probably because the early adopters have few role models and face few expectations in this respect" [34].

Consumer perceptions influence consumer behaviour, so there may be situations in which "some sustainable behaviour of consumers is not adopted because they are perceived to be not normal, and some unsustainable behaviour persists because they are seen as normal". Thus, marketing strategies can be influential by (re)positioning these perceptions [35].

One of the widely debated strategies in specialized literature is green marketing. Green marketing has become a sustainable alternative to conventional marketing, being a concept adopted by consumers, producers and governments in order to save natural resources and environmental protection as society as a whole becomes more concerned with these issues [36].

Green marketing has an important role to play in supporting green consumption, contributing to a better promotion of green products and the benefits of using these products by consumers. Statistics show that the consumption of green products has increased in recent years, however, the increase has not been spectacular, and especially because of the economic and financial crisis that has affected this sector. However, green marketing can stimulate green consumption, as long as producers are truly environmentally responsible without exaggerating the properties of a bio product.

An environmentally oriented production obtained by incorporating organic component among a firm's strategic priorities, can turn green marketing into one of the most important strategic elements that determine consumer behavior change and requires rethinking production and marketing company [37].

Green Marketing is addressed in many studies and is often quoted when talking about sustainable development. Its role is very important for the success of eco-development objective, which depends overwhelmingly by consumer preferences.

Consumer education and information are important to influence consumer behaviour, but other factors are just as important, such as: consumer perceptions, price of products, culture, care for the environment and the level of development of society.

Concepts such as ecologic marketing or environmental marketing are used to refer to green marketing. The first term appeared in the literature was the ecologic marketing, used in 1975 at the workshop American Marketing Association entitled Ecological Marketing, defined as "the study of positive and negative aspects of marketing activities, pollution, energy depletion and depletion of non-energy resources" [38]. Being a relatively new term, not only for developed countries, and especially for the former communist countries (for which the concern for green issues appeared later in the last two decades), green marketing concept was used after 1980, as an initiative towards environmental protection gain popularity [39].

Pride and Ferrel [40] define green marketing as all activities of an organization to design, promote, set a price and distribute environmentally friendly products. Green Marketing is the tool that promotes sustainable activities of a company [41] but green marketing strategy success depends on how it responds to the needs and expectations of consumers.

"Green Marketing is the management process responsible for identifying, anticipating and satisfying consumer and company requirements in a profitable and sustainable way" [42]. Polonsky [43] points out, that the definition of green marketing says that consumer needs or producer's wants have to be fulfilled trying to minimize negative impacts on the natural environment. As he and other authors [44] refer to the need to reduce environmental impacts in the production, sales and consumption processes. 
The green marketing is geared towards environmental protection and the quality of life, its purpose being that of identifying the problems facing society and consumers, to the effects of economic activities on the environment and support opportunities for the firm to adopt competitive strategies but positive impact on the environment. Green Marketing aims at fulfilling three principles: social responsibility, holistic and economic and social sustainability [45].

Environmental issues have to be included in all stages of marketing, beginning at the first stage, the development of new products [46]. The green products are an essential element of the concept of green marketing, being appreciated by some experts as being vital for the survival and expansion of business [47]. According to Ottman [48], the green quality of a product can be guaranteed by ensuring both environmental improvement and customer satisfaction. Failure to address both goals or overrate one of them is considered "green marketing myopia".

Green marketing strategies can be the decisive element in adapting to new consumer requirements and can be a source of competitive advantage at national or regional levels in the long term. Short-term investments can be seen in technology costs, staff qualifications, and monitoring of production processes, but by reducing consumption of energy and raw materials, green marketing strategies can help firms to become competitive in the long term by providing economic benefits. We thus reach a win-win position in which both environmental benefits and increased competitiveness are obtained simultaneously.

Green issues involve additional costs and therefore higher prices. Consumers will pay more if they identify the product has additional value or benefit, and the extra cost will be accepted, which is directly correlated with the importance the consumer attaches to human health and the environment. Sometimes, in some economies, such as Romania, consumer behavior is guided by price and less by concerns about the environment. This raises the need for campaigns, on the one hand, that increase knowledge and understanding of the importance of these factors so consumers are willing to accept the additional costs involved in the production and distribution of green products and, on the other hand, that differentiate, through certifications and authentication, green production from the rest of the production.

Environmentally responsible behaviour can be stimulated, at the organizational level, by techniques for influencing attitudes and behaviours of employees within organizations, by ensuring employee commitment to the values and environmental objectives of the organization, through training and education and by providing a work environment in which employees voluntarily engage in environmentally responsible activities. Environmental concern should be manifested by the individual's behaviour both at home and at work. Organizations are recognizing the need to respond to the imperatives of the environment by implementing policies and objectives aimed at protecting the environment, the employment of specialist staff, investing in new technologies and encouraging people to change their behaviour by providing facilities and training. In turn, employees create new environmentally friendly ways of working and can influence others to adopt responsible behaviour towards the environment, being a valuable resource for the organization [49].

The advantages offered by green marketing [50] are related not only to the environment but also to reducing trade barriers and to the standardization of products. This can reduce problems related to consumer health and safety. In addition, Porter and Linde [51] considers that the additional costs involved in adaptation to standards and regulations can stimulate innovation which, in turn, may partially or fully offset the costs of compliance with these standards.

The challenge of green marketing is to not only identify green customer segments or consumers who consume environmentally friendly goods and are willing to pay extra for them, but also to establish a consensus regarding green products. Without clear rules about what these products are it is difficult to assess success and there is little way to offer incentives for producers to advance in this direction [52]. 
Therefore, most often, green marketing oriented firms respond to increasing pressure of society, following the rules and regulations set out by the appropriate bodies at national or international levels, or as a result of consumer demand.

It is estimated that companies can influence consumer orientation towards green products through green marketing and consumer education to improve environmental awareness of the importance and benefits of using green products [53]. In the Western world, a shift towards increased awareness of green issues by most consumers can be seen by looking at the data [54].

Green marketing is an area that extends beyond promoting goods that are directly related to the environment. This concept refers both to industrial products or services that are advertised as having minimal impact on the environment or that are not in opposition to it. Such approaches can be seen in tourism or agriculture areas arising from increasingly frequent references to "eco" or "green" when characterizing various activities, including marketing.

Green marketing in agriculture is a branch of social marketing, which aims to protect the soil, water, and air from the pollution and degradation of agricultural production and involves the introduction of environmental technologies, which draws on evidence provided by nature, in order to protect nature [55]. It is a discipline of marketing to create safe products necessary for a healthy society and environment, taking into account the general interests of society.

Some authors point out that on many occasions green marketing has failed to make the expected impact, because companies can be accused of misleading consumers when they do not present correctly and completely the characteristics of a product or intentionally omit certain details, or because the message sent by green marketers is superficial and is not perceived properly. Companies using improper practices can lose a lot: reputation, compromised business from violating the legislation [56].

In practice, some companies abuse the green marketing strategy by putting more emphasis on promotion than on achieving a truly green business. This is called greenwashing. Green marketing has to be authentic, to inform consumers fully and accurately about products and services, and the social and environmental impact throughout the entire product life cycle [57]. Authentic green marketing will help increase consumer confidence and satisfaction in products, which will encourage repeat purchase of these products, and thus a win for both the consumer and the provider [58].

There are opinions in the scientific literature according to which green marketing has not achieved its goal of changing consumer spending habits, but the awareness of the benefits of green economy and environmental responsibility is formed over time and depends on culture, education and societal development.

Just because progress is slow, we do not have to give up on stimulating green consumption and production, by any means, as long as marketing efforts are authentic and comply with the law.

\subsection{Green Marketing in Romania}

Over the last years, the interest for green products increased in Romania, both for those aimed at organic food, and for those aimed at renewable energy.

As an EU member state, Romania has to aim to achieve sustainable economic development, and environmental protection must become a priority.

Analysis of environmental performances of companies in Romania is performed every year by the Green Revolution Association and Green Business Index reports. According to the Green Business Index 2015 Report [59], the progress made by the Romanian companies can be noticed in the field of environmental protection. On the other hand, the situation of legal conformity related to environment, promotion of sustainability at company level, training of environment managers of environment departments, require urgent improvement.

The evaluation of companies' responsibility for the environment is analyzed in GBI Report on seven levels regarding: sustainable development, use of resources, impact on environment, wastes management, buildings and green spaces, green acquisitions and sustainable transportation. 
In some fields, the GBI results were good, because certain companies invested in the reduction of atmosphere pollution. In other fields, such as green acquisitions, green buildings and use of resources, the results were poor.

Another problem is the reduced participation of Romanian companies in the realization of this report. Among the participating companies, which got better results in the services and production fields, the poorest results were registered by the companies in construction, because the activities in this field are more difficult to control and monitor by environmental authorities.

The assessment of the Romanian companies, regarding their involvement in the seven fields of analysis, is based on the following indicators: impact on environment (from the point of view of emissions in atmosphere, water and soil pollution, management of environmental emergencies), sustainable development (which aims at environmental policy, plans and programs of environmental actions, sustainability of products, costs and benefits with environmental management) and wastes management (regarding the situation of waste generation in company, policy, audit, planning and conformity in waste management and valorization).

In Romania, green economy development and application of green marketing strategies are only in their early stages. Moldovan shows that, in Romania, even though some companies have embraced the sustainability agenda, they have not done much to change their short-term orientation to profit with long-run strategies in favor of sustainable development [60].

The support of green marketing strategies was firstly given by multinational companies, which demonstrated a greater concern for environmental protection. As Sima shows, green marketing strategies are not adopted on a wide scale in Romania, but the fields in which we can speak about the application of green marketing campaigns are: the agricultural sector-in organic farming, the field of cleaning companies-which use bio-degradable or organic and natural cleaning methods, the field of food products-if the products are obtained from organic raw materials and environmentally-friendly technologies, or the manufacturing sector-which uses raw materials from recycled products [61,62].

A remarkable contribution regarding the promotion of green products and environmentally friendly behavior has been made in Romania by NGOs, by using different marketing techniques. According to a study by Neagu, all the companies and NGOs analyzed draw on educational tools as part of their marketing, through ecology lessons, providing information about pollution and ecological products and the protection of the environment. A low number of companies reach the next level of a marketing strategy, which is the affective level, in which personalities from different fields who become consumer role models are involved in promotion. [63] Another technique used is action stimulation, by which direct learning experiences are offered resorting to campaigns such as planting trees, collection of wastes, and building of different objects from recycled materials [63].

The development of green marketing strategies in Romania is based on the need to stimulate and remodel the behavior and lifestyle of people, according to the legislation and environmental standards, which supports the development of a green economy. However, we cannot speak about green marketing strategies as long as the concern for the environment is reduced. The progress made by Romanian companies in the field of responsibility for the environment is the starting point in the transfer to green strategies, both in the field of management, production, outlet, technologies and marketing. All these strategies have to take into account changes in the business, economic and social environments and adjust to them.

\subsection{Green Marketing as a Strategy to Support Organic Farming in Romania}

The agricultural sector plays an important role in the sustainable development of any economy. It supports the development of other sectors and contributes to modernizing an economy, in particular through the interdependence between agriculture and industry [64]. Development of organic farming can be combined with expanding production of renewable energy, thereby generating positive effects in economic terms, but especially in terms of developing a green economy [65]. 
Considering that the development of organic farming in Romania is in its early stages and the Romanian consumer does not pay particular attention to organic products, we can consider that one of the strategies which Romanian farms should have in view for the promotion of their own products is a green marketing strategy. In order to be competitive on the market, Romanian farms should develop their own outlet markets, attract and maintain their customers, extend the business, and use state-of-the-art technologies.

Marketing strategies can focus on market orientation, competitive orientation or social orientation. Different types of strategies can complement each other, choosing one or the other by examining strategies for various selection processes, as well as a consistency test (measures the compatibility strategy with business objectives), test resources (showing the extent to which resources can implement a strategy), cost-restrictions (measured costs in overcoming various limitations of implementing a strategy) [66].

Green marketing in agriculture aims to integrate environmental aspects to economic decisions on agricultural development and environmental conservation. Green marketing encourages the development of sustainable organic agriculture, which contributes to improving the quality of life both for the present and for the future.

The last decades marked significant changes in terms of the production, certification, authentication and distribution of products in all sectors, including agriculture, focusing increasingly more on issues about safe consumption or production in environmentally friendly ways. Consumers are beginning to understand the importance of these issues and become more responsive to changes imposed by eco-development, adopting a selective consumer behavior in terms of increasing income and changes in lifestyle.

Greening agriculture and adoption of green marketing strategies in agriculture is of increasing concern, due to stronger policies being implemented by the EU as a result of climate change, pollution, and increased need for soil conservation, efficient water management and biodiversity protection. In this respect, negative environmental impacts can be reduced by using compounds that do not affect soil quality or the environment and human health. Natural resources are limited and they should be used to meet consumer needs and to achieve the objective of an organization without harming the environment [67].

There are two aspects that are perceived by certain organizations as moral obligations in the sense of being more socially responsible. For them, green marketing is considered a handy solution [68]. From this point of view, agricultural green marketing involves the following two aspects:

(1) Health and consumer safety. Increased incidence among young people and adults of diseases such as metabolic and nutritional cause awareness of the need-oriented agricultural products produced in green. Given the much diversified offering, it is of major importance to green products a part from the rest of production. National public authorities are essential for this type of survey and certification of production. The fact that certain standards are not mandatory for manufacturers increases the need for green marketing to inform and sensitize consumers about the benefits of production or consumption of certain products may have on human health and the environment.

(2) Environmental protection both in manufacturing and in the sales of the product in any field, not just in agriculture.

In particular, in agriculture, green marketing involves reducing the use of toxic, expensive energy based organic fuel, increasing the use of renewable materials and recycling, resource conservation without the use of harmful chemicals, use of raw materials and packaging biodegradable, recyclable or reusable.

Green marketing in agriculture includes all conventional marketing mix elements as defined by Neil Borden, with the difference that each element comprises, in addition to traditional features, some other features [69]. 
(1) Obtaining/producing the product has to protect the environment (no pollution and pesticides);

(2) Price is usually higher, but green consumers accept it;

(3) Placement (distribution) includes ecological packaging, but also longer-term storage of goods;

(4) Promotion focuses on environmental issues [70].

The common characteristic of all elements is therefore that it does not adversely affect consumers, resources and the environment, aimed at meeting the needs of all participants in the production, distribution and consumption processes [40].

In Romania, the growing importance of green organic product has meant that current marketing strategies are reworked to promote green products on the domestic and international market. Even if the domestic market is not sufficiently trained yet for the large consumption of organic products, Romania can develop these products for export. About $90 \%$ of organic food production is exported; the main products exported are cereals, dairy products, vegetables, fruits, medicinal plants and honey. Danciu considers that sending the largest part of this production to export is related to the lack of distribution channels and outlet channels on the domestic market, and the lack of promotion for these products. That is why green marketing can contribute to the increase of consumption of green products in Romania by informing the consumer. In the purchasing decision, the starting point is drawing attention to that product by marketing strategies, followed by the stage when the consumer informs him/herself about the product, then can make the purchasing decision and acts by buying it [71].

Initially, the adjustment of Romanian farms to the requirements of organic production came from the desire to export these goods, but gradually the Romanian market has begun to grow [72].

The alliance between green marketing and Romanian farming practices must start with the following objectives:

(1) Winning the consumer's trust both on the domestic market and on the external market. Several studies show that the consumer's attitude regarding green products represents the starting point in the development of a business with green products;

(2) Evaluation of market size, competitors and knowledge of green standards;

(3) Evaluation of a market's specificity from commercial and organic points of view (prices, demand of green products, distribution system, which allows the realization of a real cost plan and establishment of suitable marketing strategies).

The green marketing strategies adopted by Romanian farms focused especially on the penetration of international markets and implied the realization of strategic alliances with foreign partners who distribute or organize the distribution of their products, many times under the names of foreign brands. This represents a strategy of penetration of different markets, because these companies do not have experience in the field [72].

The development of a domestic market of green products involves changing mentalities and lifestyles. Even if the purchasing power of Romanians is on the rise, the higher prices of these products are a factor for Romanian consumers, which are a result of the higher production costs compared to that of conventional products. These costs include, apart from more expensive ingredients, also costs with certification of green products and their labeling, which require industrial installations and packaging specific to organic farming standards.

However, the development potential of the organic market in Romania is supported by many studies $[61,62,71,72]$, which show that progress has been made in this field, because the costs of producing organic food are lower in Romania than in other countries, which gives Romanian products a competitive advantage.

Green marketing can be successful in a developed agricultural industry, and can, in turn, promote and support the development of green agriculture, which thus contributes to sustainable economic development. Organic farming is the way to meet the demand for natural products and also a way to diversify the agricultural sector in the overall context of environmental protection. [55,73]. 


\section{Conclusions}

Green marketing is an important field, which can contribute to green business development in agriculture. Organic agriculture has developed in recent years in Romania, but there are steps to be taken to reduce the gaps with highly developed countries.

Development of agriculture, and especially of organic farming products that are appreciated worldwide will lead to a qualitative transformation of the Romanian economy.

Romania has agricultural potential that gives it the chance to develop organic farming and to penetrate different internal and international markets. For this, however, efforts need to be continued, both at the farm level, as a company able to compete on the market, and at the governmental level through policies that support this industry. Public policies can also be useful in educating businesses and consumers about their responsibility towards the environment, by promoting projects and initiatives that bring people closer to nature [1].

As emerges from the analysis of the convergence of Romania to the EU in terms of growth rate of agricultural land used for organic production, our country is on a path of positive development of organic agriculture. This is a niche market for Romania to be harnessed, especially through policies to stimulate business and investment in the field. Important to the industry's further development is attracting and using European funds.

However, the general objectives of development of ecological agriculture are avoiding any form of pollution, ensuring soil fertility, ensuring the production of natural and healthy good, and providing a decent standard of living for farmers.

Interventions are required from government bodies to update and improve legal standards regarding the environment, as well as their implementation by the relevant institutions. Such rules, if applicable to all, will lead to the elimination of the additional costs of green business.

Adopting green marketing in agriculture involves acceptance by the various participants (producers, consumers) of the costs and benefits of green products, both in the short term and long term.

Thus, with growing interest in the development of organic farming in Romania, green marketing plays an increasingly important role in promoting the benefits of organic food consumption, contributing to business development with organic products, and also to the development of Romanian agriculture. Promotion of organic farming through the use of green marketing is useful for improving human health, the environment and the economy in the context of sustainable development.

Conflicts of Interest: The author declares no conflict of interest.

\section{References}

1. Luchs, M.G.; Phipps, M.; Hill, T. Exploring consumer responsibility for sustainable consumption. J. Market. Manag. 2015, 31, 1449-1471. [CrossRef]

2. United Nations Environment Programme (UNEP). Food Waste Facts. Available online: http:/ /www.unep. org/wed/2013/quickfacts / (accessed on 30 October 2015).

3. Soule, C.A.A.; Reich, B.J. Less is more: Is a green demarketing strategy sustainable? J. Market. Manag. 2015, 31, 1403-1427. [CrossRef]

4. Baranski, M.; Srednicka, T.D.; Volakakis, N.; Seal, C.; Sanderson, R.; Stewart, G.B.; Benbrook, C.; Biavati, B.; Markellou, E.; Giotis, C.; et al. Higher antioxidant and lower cadmium concentrations and lower incidence of pesticide residues in organically grown crops: A systematic literature review and meta-analyses. Br. J. Nutr. 2014, 112, 794-811. [CrossRef] [PubMed]

5. Pamfilie, R.; Voinea, L. Innovation management-Applications in the foodstuff offer field. Quality Access Success 2009, 10, 7-8.

6. Dangour, A.D.; Dodhia, S.K.; Hayter, A.; Allen, E.; Lock, K.; Uauy, R. Nutritional quality of organic foods: A systematic review. Am. J. Clin. Nutr. 2009, 90, 680-685. [CrossRef] [PubMed]

7. European Commission. Agriculture. A Partnership between Europe and Farmers. Available online: http:/ / europa.eu/pol/pdf/flipbook/en/agriculture_en.pdf (accessed on 5 October 2015). 
8. Michelsen, J. The Role of Research, Information and Communication. In Organic Agriculture: Sustainability, Market and Policies; Cabi Publishing: Cambridge, MA, USA, 2003; pp. 367-377.

9. Michelsen, J.; Soegaard, V. Policy Instruments for Promoting Conversion to Organic Farming and Their Effects in Europe 1985-97; Syddansk University, Institut for Statskundskab: Odense M, Denmark, 2001.

10. Offermann, F. The influence of the EU common agricultural policy on the competitiveness of organic farming. In Organic Agriculture: Sustainability, Market and Policies; Cabi Publishing: Cambridge, MA, USA, 2003.

11. IFOAM EU Group. Organic in Europe: Prospects and Developments (2014). Available online: http:/ / www.organiceurope.net/europe-europe-eu/europe-publications/oe-pub-organic-europe-2014.html?L=0 (accessed on 2 November 2015).

12. Crowder, D.; Reganold, J. Financial competitiveness of organic agriculture on a global scale. Proc. Natl. Acad. Sci. Unit. States Am. 2015, 112, 7611-7616. [CrossRef] [PubMed]

13. Hokazono, S.; Hayashi, K. Variability in environmental impacts during conversion from conventional to organic farming: A comparison among three rice production systems in Japan. J. Clean. Prod. 2012, 28, 101-112. [CrossRef]

14. Sgroi, F.; Fodera, M.; di Trapani, A.M.; Tudisca, S.; Testa, R. Cost-benefit analysis: A comparison between conventional and organic olive growing in the Mediterranean area. Ecol. Eng. 2015, 82, 542-546. [CrossRef]

15. Testa, R.; Fodera, M.; di Trapani, A.M.; Tudisca, S.; Sgroi, F. Choice between alternative investments in agriculture: The role of organic farming to avoid the abandonment of rural areas. Ecol. Eng. 2015, 83, $227-232$. [CrossRef]

16. Mohamad, R.S.; Verrastro, V.; Cardone, G.; Bteich, M.R.; Favia, M.; Moretti, M.; Roma, R. Optimization of organic and conventional olive agricultural practices from a Life Cycle Assessment and Life Cycle Costing perspectives. J. Clean. Prod. 2014, 70, 78-89. [CrossRef]

17. Orlund, K. Norwegian experience with conversion and support payments for organic farming. In Organic Agriculture: Sustainability, Market and Policies; Cabi Publishing: Cambridge, MA, USA, 2003.

18. Beckford, C.; Campbell, D.; Barker, D. Sustainable Food Production Systems and Food Security: Economic and Environmental Imperatives in Yam Cultivation in Trelawny, Jamaica. Sustainability 2011, 3, 541-561. [CrossRef]

19. Serban, A.C. Education and changing labour content-Implications on employment. Actual Probl. Econ. 2012, 136, 536-543.

20. World Bank. Agriculture, Value Added (\% of GDP). Available online: http://data.worldbank.org/ indicator/NV.AGR.TOTL.ZS/countries (accessed on 20 January 2016).

21. World Bank. Employment in Agriculture (\% of total employment). Available online: http://data.worldbank. org/indicator/SL.AGR.EMPL.ZS/countries (accessed on 20 January 2016).

22. European Commission. Action Plan for Future Organic Production in European Union, Bruxelles. Available online: http:/ / ec.europa.eu/agriculture/organic/documents/eu-policy/european-action-plan/act_en.pdf (accessed on 4 September 2015).

23. European Commission. Eurostat. European Statistics, Area under organic farming. 2015. Available online: http:/ / ec.europa.eu/eurostat/tgm/table.do?tab=table\&init=1\&language=en\&pcode=tsdpc440\&plugin=1 (accessed on 2 November 2015).

24. Voinea, L.; Popescu, D.V.; Negrea, M.T. Good practices in educating and informing the new generation of consumers on organic foodstuffs. Amfiteatru Econ. J. 2015, 17, 357-375.

25. The Ministry of Agriculture and Rural Development. Dinamica operatorilor si a suprafetelor in agricultura ecologica. Available online: http://www.madr.ro/agricultura-ecologica/dinamica-operatorilor-si-asuprafetelor-in-agricultura-ecologica.html (accessed on 15 September 2015). (In Romanian).

26. European Commission. Eurostat, European Statistics, Cerified organic crop area by crops products. 2015. Available online: http:/ / appsso.eurostat.ec.europa.eu/nui/show.do (accessed on 15 September 2015).

27. Farming First. Agriculture for a Green Economy: Improved Rural Livelihood, Reduced Footprint, Secure Food Supply. Available online: http://www.farmingfirst.org/wordpress/wp-content/uploads / 2011/10/Farming-First-Policy-Paper_Green-Economy.pdf (accessed on 15 November 2015).

28. Lohr, L.; Park, T. Local Selling Decisions and the Technical Efficiency of Organic Farms. Sustainability 2010, 2, 189-203. [CrossRef]

29. Pociovalisteanu, D.M.; Novo-Corti, I.; Aceleanu, M.I.; Serban, A.C.; Grecu, E. Employment Policies for a Green Economy at the European Union Level. Sustainability 2015, 7, 9231-9250. [CrossRef] 
30. Aceleanu, M.I.; Pociovalisteanu, D.M.; Novo-Corti, I.; Serban, A.C.; Burghelea, C. Green consumption-Way to a sustainable agriculture in Romania. In Proceedings of Global Cleaner Production \& Sustainable Consumption Conference, Barcelona, Spain, 1-4 November 2015.

31. Fuller, D. Sustainable Marketing. Managerial-Ecological Issues; Sage Publications: California, USA, 1999 ; p. 334.

32. Riley, L.S.; Kohlbacher, F.; Hofmeister, A. A cross-cultural analysis of pro-environmental consumer behaviour among seniors. J. Market. Manag. 2012, 28, 290-312. [CrossRef]

33. Polonsky, M.J.; Vocino, A.; Grau, A.L.; Garma, R.; Ferdous, A.S. The impact of general and carbon-related environmental knowledge on attitudes and behaviour of US consumers. J. Market. Manag. 2012, 28, 238-263. [CrossRef]

34. Thogersen, J.; Zhou, Y. Chinese consumers' adoption of a 'green' innovation-The case of organic food. J. Market. Manag. 2012, 28, 313-333. [CrossRef]

35. Rettie, R.; Burchell, K.; Riley, D. Normalising green behaviours: A new approach to sustainability marketing. J. Market. Manag. 2012, 28, 420-444. [CrossRef]

36. Rinal, S.; Preeti, P. Consumer's Environmental Concern \& Its Influence on their Purchase Intention: SEM Approach. Available online: http://www.cpmr.org.in/opinion/vol2/issue1/Articles/4.pdf (accessed on 17 September 2015).

37. Pop, N.A.; Vladoi, A.D. The marketer-A complex specialist, a man of concept, decision and action. Amfiteatru Econ. J. 2009, 11, 9-19.

38. Henion, K.E.; Kinnear, T.C. Ecological Marketing; American Marketing Association: Chicago, IL, USA, 1976; p. 168.

39. Sharma, S.; Bagoria, H. Green marketing: a gimmick or the real deal? IJRFM 2012, 2, 404-414.

40. Pride, W.M.; Ferrel, O.C. Marketing, 8th ed.; Houghton-Mifflin: Boston, MA, USA, 1993.

41. Peattie, K.; Charter, M. Green Marketing. In The Marketing Book; Butterworth-Heinemann: Oxford, UK, 2003; pp. 726-756.

42. Peattie, K. Environmental Marketing Management, Meeting the Green Challenge; Pitman Publishing: London, UK, 1995.

43. Polonsky, M.J. An introduction to green marketing. Electron. Green J. 1994, 1, 1-9.

44. Stanton, W.J.; Futrell, C. Fundamentals of Marketing, 8th ed.; McGraw-Hill Book Company: New York, NY, USA, 1987.

45. Funaru, M. Marketingul ecologic - optiune strategica in dezvoltarea firmelor romanesti. Available online: http:/ /webbut.unitbv.ro/teze/rezumate/2012/rom/FunaruMihaela.pdf (accessed on 15 August 2015). (In Romanian)

46. Ottman, J.; Terry, V. Strategic Marketing of Greener Products. J. Sustain. Prod. Des. 1998, 5, 53-57.

47. Gupta, D. Growth of Green Products, in Green Marketing Strategies; ICFAI University Press: Hyderabad, India, 2008; pp. 12-20.

48. Ottman, A. Green Marketing Myopia. Environ. Sci. Policy Sustain. Dev. 2006, 48, 21-36.

49. Smith, A.M.; O'Sullivan, T. Environmentally responsible behaviour in the workplace: An internal social marketing approach. J. Market. Manag. 2012, 28, 469-493. [CrossRef]

50. Kuhre, W.L. Environmental Labelling-Marketing; Prentice-Hall: Englewood Cliffs, NJ, USA, 1995.

51. Porter, M.E.; Linde, C. Toward a New Conception of the Environment-Competitiveness Relationship. J. Econ. Perspect. 1995, 9, 97-118. [CrossRef]

52. Ahmad, A.Y. A synthesis of green marketing concept as a recipe for healthy environment in Nigeria. IJBRM 2014, 3, 1-8.

53. Wong, V.; Turner, W.; Stoneman, P. Marketing strategies and market prospects for environmentally friendly consumer products. Br. J. Manag. 1996, 7, 263-281. [CrossRef]

54. Ghose, A. History, Growth and Challenges of Green Products, in Green Marketing Strategies; ICFAI University Press: Hyderabad, India, 2008; pp. 3-11.

55. Stoian, M. Ecomarketing; ASE Publishing House: Bucharest, Romania, 2003.

56. Strategic Sustainability Consulting. Green Marketing: Think Before You Act. Available online: http:/ / www.sustainabilityconsulting.com/ extra-resources/ green-marketing-think-before-you-act.html (accessed on 2 November 2015).

57. Dinu, V. Organizations' responsability to consumers. Amfiteatru Econ. J. 2014, 16, 6-9. 
58. Cvijanovic, D.; Mihailovic, B.; Cavlin, M.; Cavlin, G. Impact of Marketing Consulting on Performances of Agrarian Clusters in Serbia. Sustainability 2015, 7, 1099-1115. [CrossRef]

59. Green Business Index. Green Business Index 2015. Available online: https://www.gbindex.ro/wp-content/ uploads/2015/11/Raport-Green-Business-Index-2015.pdf (accessed on 2 February 2016).

60. Moldovan Gavril, I.A. Does the Financial System Promote Sustainable Development? Evidence from Eastern European Countries, Central European Business Review. Available online: http://cebr.vse.cz/cebr/ article/view/187 (accessed on 3 February 2016).

61. Sima, V. Organic Market in Romania. Actual Trends. Available online: http://www.wseas.us/e-library/ conferences/2013/Chania/BAMPD/BAMPD-05.pdf (accessed on 2 February 2016).

62. Sima, V. B2B Green Marketing in Romania, Economic Insights-Trends and Challenges. Available online: http:/ / www.upg-bulletin-se.ro/archive/2013-1/15.Sima.pdf (accessed on 2 February 2016).

63. Neagu, O. Influencing the Environmental Behavior through the Green Marketing. The Case of Romania. Available online: http:/ / www.ipedr.com/vol11/41-W00022.pdf (accessed on 27 January 2016).

64. Stringer, R. How Important are the 'Non-Traditional' Economic Roles of Agriculture in Development? Centre for International Economic Studies; Adelaide University: Adelaide SA, Australia, 2001.

65. Grecu, E. New Technologies-Between Business and Environmental Protection in Romania. Environ. Eng. Manag. J. 2014, 13, 1873-1879.

66. Zaharie, B.; Stoleru, V. Initiative de marketing pentru produsele agricole ecologice. Available online: http://www.univagro-iasi.ro/PT/Centru_pilot/ro/materiale\%20publicate/brosura.pdf (accessed 15 August 2015). (In Romanian)

67. Orange, E. From eco-friendly to eco-intelligent. Futur. J. 2010, 44, $28-32$.

68. Davis, J.J. Strategies for Environmental Advertising. J. Consum. Market. 1993, 10, 19-36. [CrossRef]

69. Khan, F.M.; Ahmad, S. Managerial Issues for Green Marketing in Food Processing Industry of India. IJAFST 2014, 5, 125-134.

70. Schwartz, G. Science in Marketing; Wiley: New York, NY, USA, 1965.

71. Danciu, V. The Organic Products in the Green Marketing Laboratory. Available online: http://store.ectap.ro/ articole/274.pdf (Accessed on 25 January 2016).

72. Gurau, C.; Ranchhod, A. International green marketing: A comparative study of British and Romanian firms. Int. Market. Rev. 2005, 22, 547-561.

73. Danciu, V. Marketing ecologic: etica verde a productiei si consumului; Economic Publishing House: Bucharest, Romania, 2006. (In Romanian) 